\title{
Temporal and ontogenetic variations in feeding habits of Hollandichthys multifasciatus (Teleostei: Characidae) in coastal Atlantic rainforest streams, southern Brazil
}

\author{
Vinícius Abilhoa $^{1}$, Hugo Bornatowski ${ }^{1,2}$ and Gislaine Otto ${ }^{1,2}$
}

Feeding habits of the characin Hollandichthys multifasciatus were investigated. Samplings were made between March 2004 and February 2005 in two black water streams of the coastal Atlantic rainforest in southern Brazil. The diet, evaluated by qualitative and quantitative methods, included aquatic and terrestrial insects, decapods, oligochaetes, plants and spiders. Large individuals feed mainly on plants, terrestrial insects, and spiders, whereas small fish feed basically on plants and oligochaetes. The species showed an omnivorous feeding habit, and its diet was composed of autochthonous (mainly oligochaetes) and allochthonous (plants and terrestrial insects) material.

Neste estudo foram investigados os hábitos alimentares do caracídeo Hollandichthys multifasciatus. Amostras foram obtidas entre março de 2004 e fevereiro de 2005, em dois riachos de água escura da Floresta Atlântica Costeira do Sul do Brasil. A dieta, avaliada por métodos quantitativos e qualitativos, inclui insetos aquáticos e terrestres, decápodes, oligoquetos aquáticos, plantas e aranhas. Os maiores indivíduos alimentaram-se principalmente de plantas, insetos terrestres e aranhas, enquanto que os menores indivíduos alimentaram-se basicamente de plantas e oligoquetos aquáticos. A espécie apresentou hábito alimentar onívoro, e sua dieta no riacho estudado foi composta por material autóctone (principalmente oligoquetos aquáticos) e alóctone (plantas e insetos terrestres).

Key words: Characin, Diet, Feeding ecology, Freshwater, Neotropics.

\section{Introduction}

The species Hollandichthys multifasciatus (Eigenmann \& Norris, 1900) inhabits coastal rivers from northern Rio Grande do Sul State to southern Rio de Janeiro State (Lima et al., 2003). These drainages belong to the Atlantic rainforest biome, and are inhabited basically by small-sized fish species, which dwell in streams or shallow water of rivers, showing sometimes a high rate of speciation and a high degree of geographic endemism (Castro, 1999).

Despite the frequent use of the name Hollandichthys multifasciatus for several fishes collected in the Atlantic rainforest drainages in the last few years (Sabino \& Castro, 1990; Esteves \& Lobón-Cerviá, 2001; Oyakawa et al., 2006), Bertaco (2003) recently identified a great diversity within the genus Hollandichthys, and restricted the distribution of one species to coastal rivers and islands between rio Jaraguá,
Santa Catarina State, and rio Nhundiaquara, Paraná State, in southern Brazil. Unfortunately, $H$. multifasciatus is still considered the only valid name for the genus (Buckup et al., 2007) and, because of that, it was applied to the species studied here.

Studies on the feeding habits of stream fishes have demonstrated a pronounced dependence on the food resources imported from the forest on the banks of the rivers (Costa et al., 1987; Graciolli et al., 2003, Abilhoa et al., 2007), results also recorded for $H$. multifasciatus (Sabino \& Castro, 1990; Esteves \& Lobón-Cerviá, 2001). In fact, most fish species use food items of allochthonous origin (Lowe-McConnell, 1999) and changes in the riparian vegetation can cause alteration in the feeding habits of freshwater fishes, affecting many links of the trophic chain (Barrela et al., 2000). Even though alterations in feeding habits can also be conditioned to ontogenetic development (Gerking, 1994), omnivory seems

${ }^{1}$ Grupo de Pesquisas em Ictiofauna (GPIc), Museu de História Natural Capão da Imbuia (MHNCI), Prefeitura de Curitiba, Rua Prof. Benedito Conceição, 407, 82810-080 Curitiba, PR, Brazil. vabilhoa@uol.com.br, anequim.bio@gmail.com ${ }^{2}$ Universidade Federal do Paraná (UFPR), Departamento de Zoologia, CP 2936, 69083-000 Curitiba, PR, Brazil. ottogis@gmail.com 
to be a predominant feeding strategy in small rivers in general (Pringle \& Hamazaki, 1998), since food resources for fishes are mainly supplied by the forest canopy (Esteves \& Aranha, 1999).

Therefore, the aim of this study was to describe the feeding habits of $\mathrm{H}$. multifasciatus collected in Atlantic rainforest streams in São Francisco do Sul, southern Brazil, analyzing the diet composition according to size classes and seasonal variations. This information is important for future projects in the conservation of Atlantic rainforest fish fauna, as the use of resources by these organisms has an influence on population and community interactions.

\section{Material and Methods}

The field work was carried out in two black water streams located on the island of São Francisco, State of Santa Catarina, southern Brazil (2617”S 483”'W). Investigated streams are close to each other, and considered as second order according to Strahler's (1964) classification. Both streams flow directly into rio Acaraí, which belongs to the coastal drainages of eastern Brazil province (Fig. 1). The study sites comprise remaining areas of the Coastal Atlantic rainforest, and also cleared areas with floating vegetation and herbaceous riparian vegetation (Fig. 2). Environmental factors such as $\mathrm{pH}$ and water temperature were recorded for each sample site, using a portable $\mathrm{pH}$ meter (Hanna). The speed of the water current was measured with a digital flow meter (Geopacks). Rainfall data was provided by Center of Environmental Resources Information and Hydrometeorology of Santa Catarina (Ciram-Epagri).

Twelve study trips were made from March 2004 to February 2005, each one lasting one day. Fishes were caught using a $1.50 \times 5.00 \mathrm{~m}$ seine net ( $5 \mathrm{~mm}$ mesh), operated three times in each stream (Fig. 2a). Captured specimens were fixed in the field in $10 \%$ formalin solution and brought to the laboratory of the Grupo de Pesquisas em Ictiofauna do Museu de História Natural Capão da Imbuia (MHNCI). Voucher specimens were deposited in the fish collection of the Museu de História Natural Capão da Imbuia (MHNCI 11732). Fishes were collected with authorization from IBAMA, Proc. $\mathrm{N}^{\circ}$. 02017.003935/06-26.

All specimens were weighed $(\mathrm{g})$, measured $(\mathrm{cm})$, and dissected. Stomachs were removed and their contents analyzed. For the diet analysis, frequency of occurrence (Hyslop, 1980) and percent composition (Hynes, 1950) of food items were determined for each item, as well as the alimentary index proposed by Kawakami \& Vazzoler (1980). The alimentary index was used to combine the results obtained for each food item by the frequency of occurrence and percent composition methods. The food items were grouped in broad taxonomic or ecological categories according to their origin. Immature aquatic insects (larvae and pupae), adult aquatic insects, decapods, and oligochaetes were considered as autochthonous items. Terrestrial insects, insect fragments, plants and spiders were considered as allochthonous items. The proportion of autochthonous and allochthonous items during the study period was calculated for all individuals using the alimentary feeding index, for the purpose of presenting a general view of the origin of food items.

Graphical analysis proposed by Costello (1990) to assess the proportion of food items in the diet was performed. This method consists of a two-dimensional representation of prey abundance values (e.g., percent contribution or volume) on the $y$ axis and frequency of occurrence on the $\mathrm{x}$ axis. A comparative analysis of the diet according to size class was performed in order to check for a possible influence of body size on feeding habitats. Size classes were defined according to the Sturges formulation (Silva \& Souza, 1987).

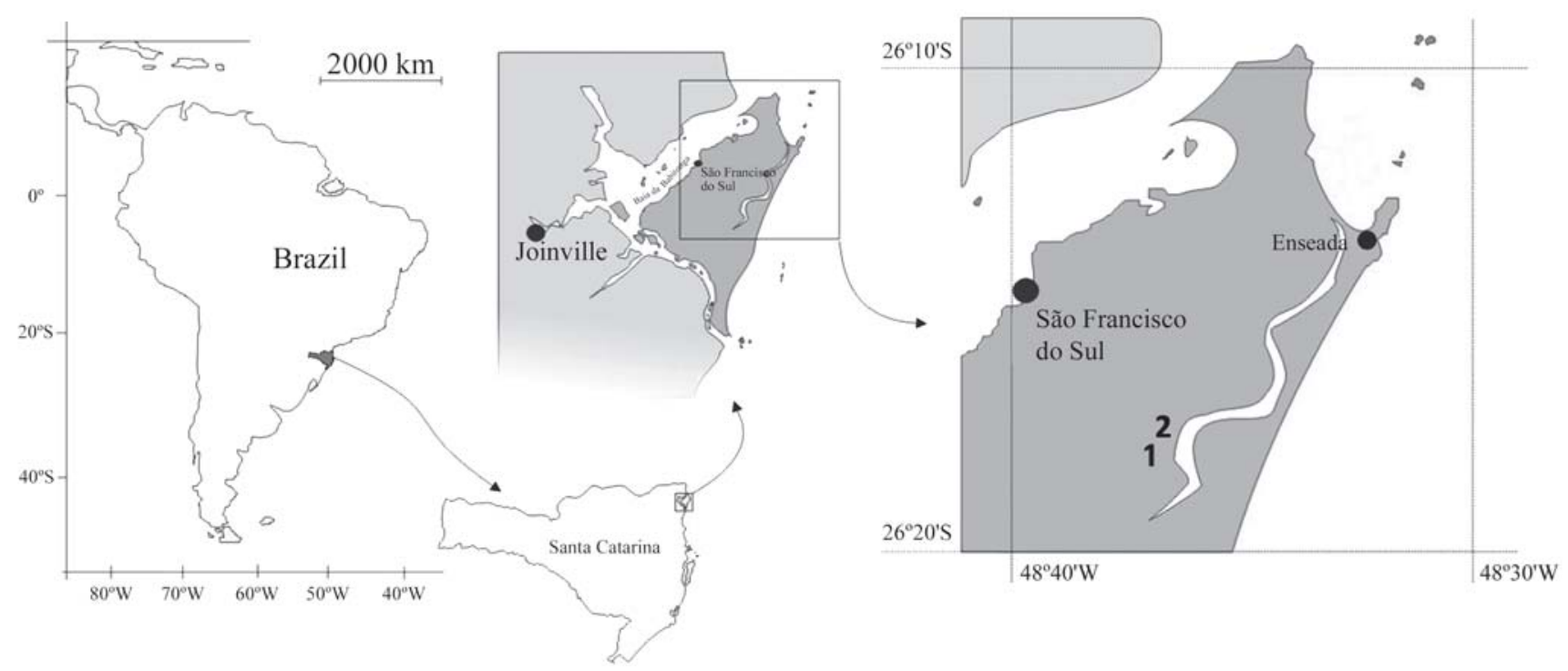

Fig. 1. Northern coast of Santa Catarina State (southern Brazil), showing the city of São Francisco do Sul and the location of the study sites $(1,2)$. 


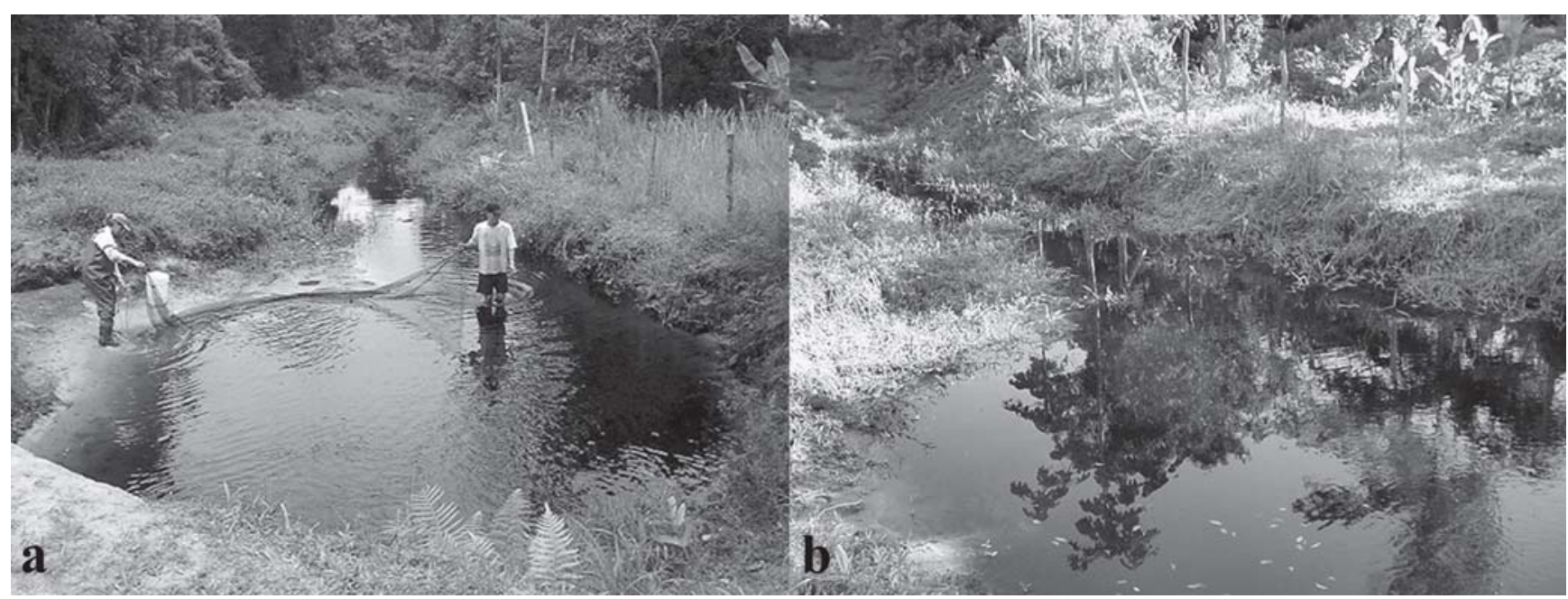

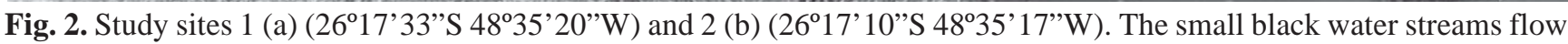
directly into rio Acaraí, in São Francisco do Sul, southern Brazil.

\section{Results}

Environmental factors (pH, water temperature and water current) showed no variations between the investigated streams (Fig. 3). The water temperature during the study period ranged from $16.9^{\circ} \mathrm{C}$ (July 2004) to $24.9^{\circ} \mathrm{C}$ (January 2005), and the daily rainfall varied from $0.3 \mathrm{~mm}$ (August 2004) to 14.48 mm (January 2005) (Fig. 4). Based on the volume of rain registered in the sample period, the samples were divided into low precipitation period (March to November 2004, and February 2005) and high precipitation period (December 2004 and January 2005) (Fig. 4).

A total of 191 individuals were caught during the study period, ranging from 19.2-96.0 mm SL. The mean standard length was smaller in March 2004 (30.7 mm), April 2004 (32.1 $\mathrm{mm}$ ), and February 2005 (32.3 mm), than in the remainder of the study period, which indicates a higher number of juveniles during the summer and autumn.

The stomach contents were composed of 23 food items, grouped in eight broad categories according to their ecological characteristics and origin: immature aquatic insects (dipteran larvae/pupae, Odonata nymphs), aquatic insects (Belostomatidae), decapods, oligochaetes, terrestrial insects (Apidae, Formicidae, Vespidae, Cecopidae, Belostomatidae, Hebridae, Notonectidae, Gryllidae, Grylotapidae, Isoptera, Blattidae, Muscidae, and Curculionidae), insect fragments, spiders and plants (fruits, seeds, and fragments). In relation to the origin of the food items, the majority of them were allochthonous (18 food items, 78.3\%). Among the autochthonous ones, the most representative were oligochaetes ( $25.1 \%$ of occurrence and $34.5 \%$ of abundance) and aquatic insects $(7.8 \%$ of occurrence and $7.8 \%$ of abundance). Plants (40.3\% of occurrence and $22.1 \%$ of abundance), terrestrial insects (22.5\% of occurrence and $16.4 \%$ of abundance) and insect fragments (19.3\% of occurrence and $13.9 \%$ of abundance) were the most important allochthonous food items (Fig. 5). The proportion of
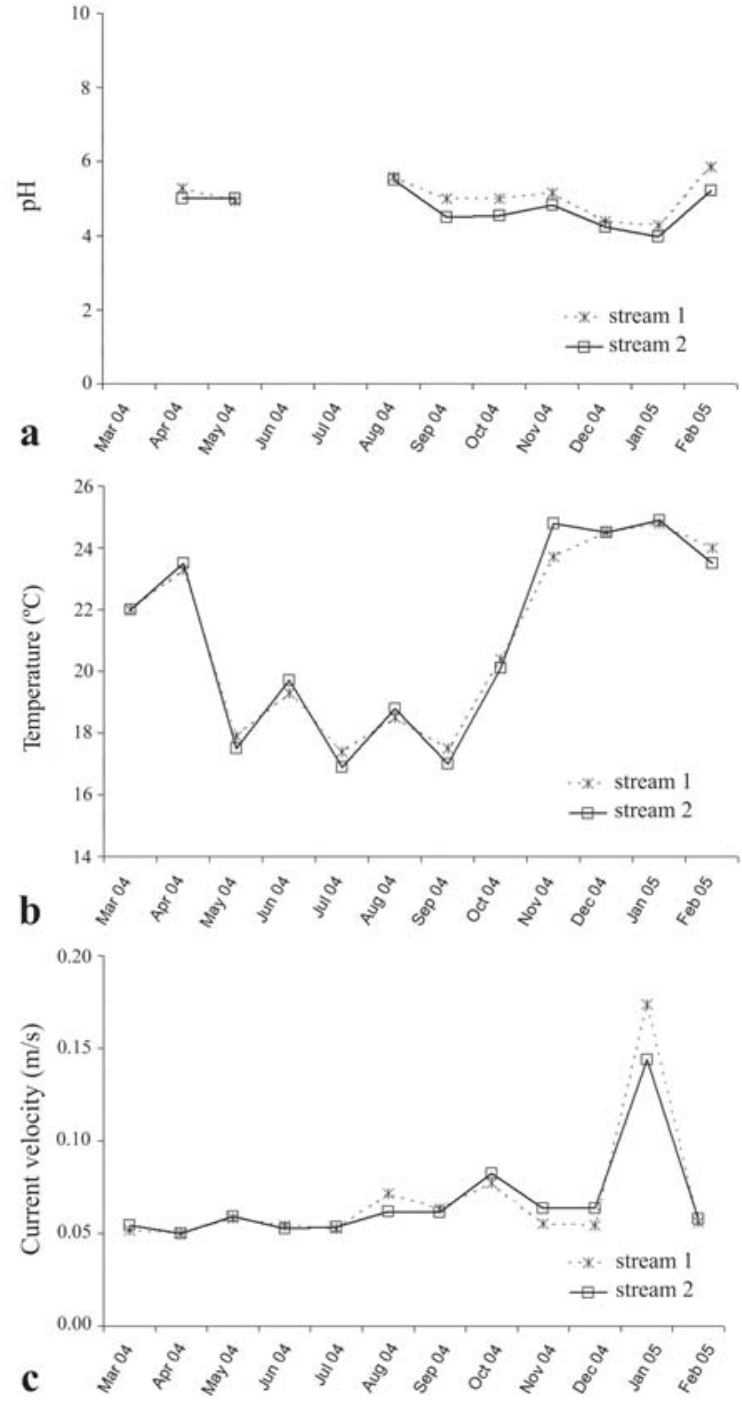

Fig. 3. Monthly distribution of the environmental factors measured $\mathrm{pH}(\mathrm{a})$, water temperature (b) and water current (c) in the streams investigated. 


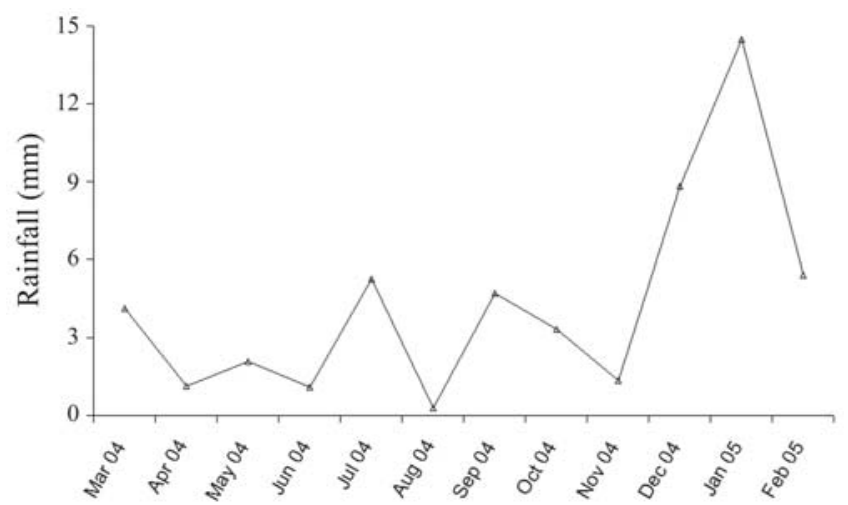

Fig. 4. Monthly variation of the rainfall (mm) in the sample period provided by the Center of Environmental Resources Information and Hydrometeorology of Santa Catarina (CiramEpagri).

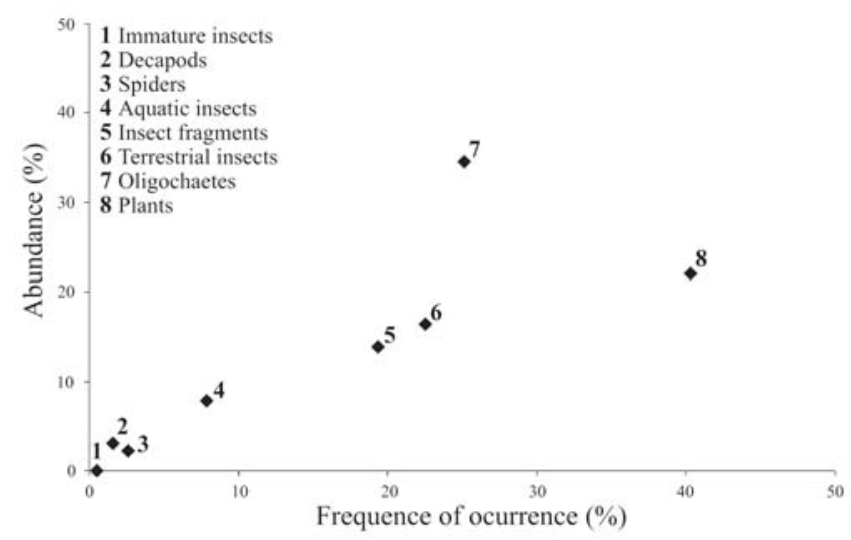

Fig. 5. Proportion of autochthonous and allochthonous food items in the diet of Hollandichthys multifasciatus according to the method proposed by Costello (1990).

autochthonous and allochthonous items in the diet of $H$. multifasciatus was different during the period studied (Fig. 6).

Data on the nine size classes showed that the items terrestrial insects, insect fragments, and plants comprised the diet of almost all individuals. However, only the size classes between 19.2 and $72.6 \mathrm{~mm}$ SL fed on oligochaetes (mainly), aquatic insects (immature and adults) and decapods, while terrestrial insects, spiders and plants were the most important food item for the size classes between 72.7 and 99.3 mm SL (Table 1).

\section{Discussion}

Most small-sized Atlantic rainforest characins are omnivorous and insectivorous (Costa, 1987; Sabino \& Castro, 1990; Aranha et al., 1998; Vitule et al., 2008), and in small to mid-order tropical streams, several fish species feed primarily on allochthonous food material, such as terrestrial insects (Costa, 1987; Allan, 1995; Casatti \& Castro, 1998; Aranha et

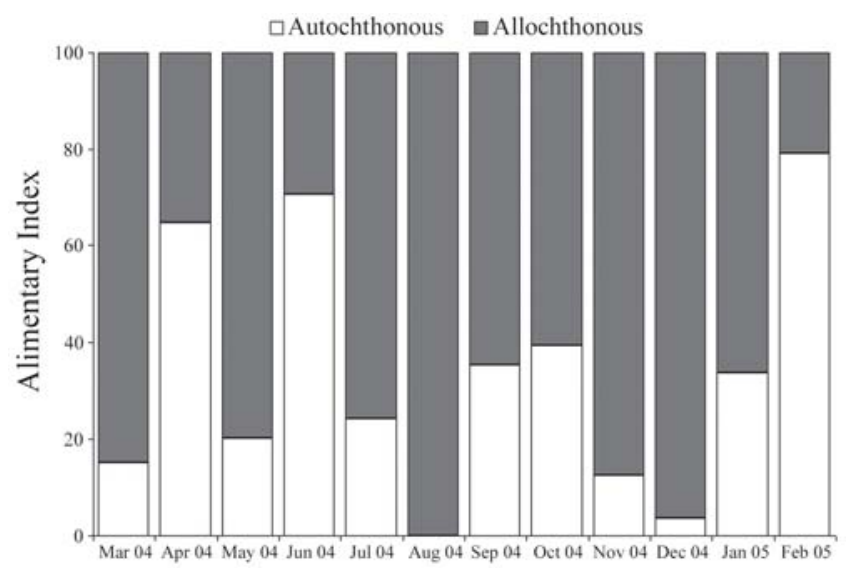

Fig. 6. Proportion of autochthonous and allochthonous food items in the diet of Hollandichthys multifasciatus during the period studied. Percentages of each category were obtained from the feeding index.

al., 1998; Sabino \& Zuanon, 1998; Abilhoa et al., 2008). In the present study, Hollandichthys multifasciatus was found to feed on autochthonous (mainly oligochaetes) and allochthonous (plants and terrestrial insects) material, and its feeding habit can be characterized as omnivorous, due to the high importance of oligochaetes, terrestrial insects and plants in the stomach contents.

Although the proportion of autochthonous and allochthonous food in the diet of $H$. multifasciatus was different during the study period, no relation between feeding habits and precipitation period was observed, even though the study site is subject to flash floods and consequently greatly variation in abiotic aquatic parameters in the rainy season, like other streams of the Coastal Atlantic rainforest (Vitule et al., 2008). Allochthonous items showed high frequency during almost all the period studied, except in April and June 2004, and February 2005, which seems to be related to food availability. In fact, terrestrial insects are considered an important food source for fishes in streams lined by forests and riparian vegetation (Lowe-McConnell, 1999). The consumption and importance of terrestrial food items for $H$. multifasciatus were also recorded by Sabino \& Castro (1990) and Esteves \& Lobón-Cerviá (2001). According to those authors and our personal observations, $H$. multifasciatus is capable of using resources in mid-water and on the surface of the streams, and the swimming behavior near the surface enables it to capture terrestrial items that fall on the water, indicating surface picking behavior as described for several characin species (Costa, 1987; Casatti \& Castro, 1998; Aranha et al., 1998; Sabino \& Zuanon, 1998), by which the fish swims upstream and catches terrestrial items on the water surface (Sazima, 1986).

Despite the observation that autochthonous and allochthonous food items were present in the diet of almost all individuals, oligochaetes, aquatic insects (immature and adults) and decapods were the main food of smaller length 
Table 1. Feeding index (FI) and frequency of occurrence (FO) of the autochthonous and allochthonous food items in the diet of Hollandichthys multifasciatus according to size class.

\begin{tabular}{|c|c|c|c|c|c|c|c|c|c|c|c|c|c|c|c|c|c|}
\hline \multirow{3}{*}{$\begin{array}{c}\text { Size } \\
\text { Classes }\end{array}$} & \multirow{3}{*}{$\mathrm{n}$} & \multicolumn{8}{|c|}{ Autochthonous } & \multicolumn{8}{|c|}{ Allochthonous } \\
\hline & & \multicolumn{2}{|c|}{$\begin{array}{l}\text { Immature } \\
\text { insects }\end{array}$} & \multicolumn{2}{|c|}{$\begin{array}{l}\text { Aquatic } \\
\text { insects }\end{array}$} & \multicolumn{2}{|c|}{ Decapods } & \multicolumn{2}{|c|}{ Oligochaetes } & \multicolumn{2}{|c|}{$\begin{array}{l}\text { Terrestrial } \\
\text { insects }\end{array}$} & \multicolumn{2}{|c|}{$\begin{array}{c}\text { Insect } \\
\text { fragments }\end{array}$} & \multicolumn{2}{|c|}{ Plants } & \multicolumn{2}{|c|}{ Spiders } \\
\hline & & FI & FO & FI & FO & FI & FO & FI & FO & FI & FO & FI & $\mathrm{FO}$ & FI & FO & FI & FO \\
\hline $19.2-28.1$ & 42 & 0.02 & 2.38 & 1.73 & 4.8 & & & 17.8 & 26.2 & 20.2 & 23.8 & 17.6 & 28.6 & 42.7 & 45.2 & & \\
\hline $28.2-37.0$ & 53 & & & 8.64 & 13.2 & & & 48.5 & 30.2 & 6.32 & 16.9 & 8.22 & 20.7 & 28.2 & 35.8 & 0.11 & 1.9 \\
\hline $37.1-45.9$ & 51 & & & 12.3 & 9.8 & & & 21.6 & 13.7 & 9.22 & 15.7 & 3.65 & 9.8 & 53.2 & 35.3 & & \\
\hline $46.0-54.8$ & 22 & & & & & 1.75 & 9.1 & 36.0 & 36.4 & 13.0 & 27.3 & 0.27 & 9.1 & 48.9 & 40.9 & & \\
\hline $54.9-63.7$ & 11 & & & 0.06 & 9.1 & 2.0 & 9.1 & 40.6 & 45.4 & 20.2 & 45.4 & 12.4 & 13.2 & 2.21 & 27.3 & 22.5 & 27.3 \\
\hline $63.8-72.6$ & 7 & & & & & & & 50.3 & 14.3 & 21.4 & 28.6 & & & 28.2 & 57.1 & & \\
\hline $72.7-81.5$ & 1 & & & & & & & & & & & 18.7 & 100 & 81.2 & 100 & & \\
\hline $81.6-90.4$ & 2 & & & & & & & & & 33.0 & 100 & 31.4 & 50 & & & 35.6 & 50 \\
\hline $90.5-99.3$ & 2 & & & & & & & & & 72.6 & 50 & & & 27.4 & 50 & & \\
\hline
\end{tabular}

classes ( $<63.7 \mathrm{~mm} \mathrm{SL}$ ), while terrestrial insects, spiders and plants were the most important food items for larger individuals (> $72.7 \mathrm{~mm} \mathrm{SL}$ ). Even though few stomachs of larger individuals were analyzed, we believe that these results confirm the fact that ontogenetic variations in feeding habits occur widely among omnivorous Atlantic rainforest stream fishes, observations also made by Vitule \& Aranha (2002), Dufech et al. (2003), Barreto \& Aranha (2006), Abilhoa et al. (2007), and Vitule et al. (2008).

Diet shift related to ontogenetic variations have been the object of broad discussion in the literature (Nikolsky, 1963; Machado-Allison \& Garcia, 1986; Winemiller, 1989; Gerking, 1994; Hahn et al., 2000). According to Lowe-McConnell (1999), in tropical environments, the majority of fish species show broad flexibility in feeding habits, which seems to be related to morphological (e.g., mouth gap) and behavioral (e.g., locomotion ability) changes during development (Wooton, 1999).

Despite the fact that this study represents a short-term survey of feeding habits and diet, the relevance of some food items to the natural diet of $H$. multifasciatus, especially terrestrial insects and plants, highlights the importance of marginal forest of Atlantic rainforest biome to the feeding habits of stream fishes.

\section{Acknowledgements}

We are grateful to Matheus Oliveira Freitas (MHNCI) for helping during field work. Lilian Casatti (IBILCE/UNESP) and two anonymous referees improved the manuscript.

\section{Literature Cited}

Abilhoa, V., L. P. Bastos \& F. Wegbecher. 2007. Feeding habits of Rachoviscus crassiceps (Teleostei: Characidae) in a coastal Atlantic rainforest stream, southern Brazil. Ichthyological Exploration of Freshwaters, 18(3): 227-232.

Abilhoa, V., L. F. Duboc \& D. P. Azevedo-Filho. 2008. A comunidade de peixes de um riacho de Floresta com Araucária, alto rio Iguaçu, sul do Brasil. Revista Brasileira de Zoologia, 25(2): 238-246.

Allan, J. D. 1995. Stream ecology: structure and function of running waters. London, Chapman and Hall, 388p.

Aranha, J. M. R., D. F. Takeuti \& T. M. Yoshimura. 1998. Habitat use and food partitioning of the fishes in a coastal stream of Atlantic Forest, Brazil. Revista de Biología Tropical, 46(4): 951-959.

Barrella, W., M. Petrere Jr., W. S. Smith \& L. F. A. Montag. 2000. As relações entre matas ciliares, os rios e os peixes. Pp. 187-207. In: Rodrigues, R. R. \& H. L. Leitão Filho (Eds.). Matas Ciliares: conservação e recuperação. São Paulo, Edusp/Fapesp, 320p.

Barreto, A. P. \& J. M. R. Aranha. 2006. Alimentação de quatro espécies de Characiformes de um riacho de Floresta Atlântica, Guaraqueçaba, Paraná, Brasil. Revista Brasileira de Zoologia, 23(3): 779-788.

Bertaco, V. A. 2003. Taxonomia e filogenia do gênero Hollandichthys Eigenmann, 1909 (Teleostei: Characidae) do sul e sudeste do Brasil. Unpublished M.S. Dissertation, Pontifícia Universidade Católica do Rio Grande do Sul, Porto Alegre, 160p.

Buckup, P. A., N. A. Menezes \& M. S. Ghazzi. 2007. Catálogo das espécies de peixes de água doce do Brasil. Rio de Janeiro, Museu Nacional, 195p.

Casatti, L. \& R. M. C. Castro. 1998. A fish community of the São Francisco River headwaters riffles, southeastern Brazil. Ichthyological Explorations of Freshwaters, 9(3): 229-242.

Castro, R. M. C. 1999. Evolução da ictiofauna de riachos sul-americanos: padrões gerais e possíveis processos causais. Pp. 139155. In: Caramaschi, E. P., R. Mazzoni, C. R. S. F. Bizerril \& P. R. Peres-Neto (Eds.). Ecologia de peixes de riachos: estado atual e perspectivas. Rio de Janeiro, Oecologia Brasiliensis VI, 260p.

Costa, W. J. E. M. 1987. Feeding habits of a fish community in a tropical coastal stream, rio Mato Grosso, Brazil. Studies on Neotropical Fauna and Environment, 22(3): 145-153.

Costello, M. J. 1990. Predator feeding strategy and prey importance: a new graphical analysis. Journal of Fish Biology, 36: 261-263.

Dufech, A. P. S., M. A. Azevedo \& C. B. Fialho. 2003. Comparative dietary analysis of two populations of Mimagoniates rheocharis (Characidae: Glandulocaudinae) from two streams of Southern Brazil. Neotropical Ichthyology, 1(1): 67-74.

Esteves, K. E. \& J. M. R. Aranha. 1999. Ecologia trófica de peixes de riacho. Pp. 157-182. In: Caramaschi, E. P., R. Mazzoni, C. R. S. F. Bizerril \& P. R. Peres-Neto (Eds.). Ecologia de peixes de riachos: estado atual e perspectivas. Rio de Janeiro, Oecologia Brasiliensis VI, 260p.

Esteves, K. E. \& J. Lobón-Cerviá. 2001. Composition and trophic structure of a fish community of a clear water Atlantic rainforest stream in southeastern Brazil. Environmental Biology of Fishes, 62: 429-440.

Gerking, S. D. 1994. Feeding ecology of fish. San Diego, California, Academic Press, 416p.

Graciolli, G., M. A. Azevedo \& F. A. G. Melo. 2003. Comparative 
study of the diet of Glandulocaudinae and Tetragonopterinae (Ostariophysi: Characidae) in a small stream in southern Brazil. Studies on Neotropical Fauna and Environment, 38(2): 95-103.

Hahn, N. S., C. S. Pavanelli \& E. K. Okada. 2000. Dental development and ontogenetic diet shifts of Roeboides paranensis Pignalberi (Osteichthyes, Characinae) in pools of the upper Rio Paraná. Revista Brasileira de Biologia, 60(1): 93-99.

Hynes, H. B. N. 1950. The food of fresh-water stickle-backs (Gasterosteus aculeatus and Pygosteus pungitius), with a review of methods used in studies of the food of fishes. Journal of Animal Ecology, 19: 36-57.

Hyslop, E. J. 1980. Stomach contents analysis - a review of method and their application. Journal of Fish Biology, 17: 411-429.

Kawakami, E. \& G. Vazzoler. 1980. Método gráfico e estimativa de índice alimentar aplicado no estudo de alimentação de peixes. Boletim do Instituto de Oceanografia, 29(2): 205-207.

Lima, F. C. T., L. R. Malabarba, P. A. Buckup, J. F. P. Silva, R. P. Vari, A. Harold, R. Benine, O. T. Oyakawa, C. S. Pavanelli, N. A. Menezes, C. A. S. Lucena, M. C. S. L. Malabarba, Z. M. S. Lucena, R. E. Reis, F. Langeani, L. Cassati, V. A. Bertaco, C. Moreira \& P. H. F. Lucinda. 2003. Genera Incertae Sedis in Characidae. Pp: 106-169. In: Reis, R. E., S. O. Kullander \& C. Ferraris (Eds.). Check List of Freshwater Fishes of South and Central America. Porto Alegre, Edipucrs, 729p.

Lowe-McConnell, R. H. 1999. Estudos Ecológicos de Comunidades de Peixes Tropicais. São Paulo, Edusp, 536p.

Machado-Allison, A. \& C. Garcia. 1986. Food habits and morphological changes during ontogeny in three serrasalmin fish species of the Venezuelan floodplains. Copeia, 1986(1): 193-195.

Nikolsky, G. V. 1963. The ecology of fishes. London, Academic Press, 352p.

Oyakawa, O. T., A. Akama, K. C. Mautari \& J. C. Nolasco. 2006. Peixes de riacho da Mata Atlântica. São Paulo, Neotrópica, 201p.

Pringle, C. M. \& T. Hamazaki. 1998. The role of omnivory in a neotropical stream: separating diurnal and nocturnal effects. Ecology, 79: 269-280.

Sabino, J. \& R. M. C. Castro. 1990. Alimentação, período de atividade e distribuição espacial dos peixes de um riacho da floresta Atlântica (sudeste do Brasil). Revista Brasileira de Biologia, 50(1): 23-26.

Sabino, J. \& J. Zuanon. 1998. A stream fish assemblage in Central Amazonia: distribution, activity patterns and feeding behavior. Icthyological Exploration of Freshwaters, 8(3): 201-210.

Sazima, I. 1986. Similarities in feeding behavior between some marine and freshwater fishes in two tropical communities. Journal of Fish Biology, 29: 53-65.

Silva, J. X. \& M. J. L. Souza. 1987. Análise ambiental. Rio de Janeiro, UFRJ, 196p.

Strahler, A. 1964. Quantitative geomorphology of drainage basins and channel networks. Pp. 39-76. In: Chow, V. (Ed.). Handbook of applied hydrology. New York, McGraw-Hill.

Vitule, J. R. S. \& J. M. R. Aranha. 2002. Ecologia alimentar do lambari Deuterodon langei Travassos, 1957 (Characidae, Tetragonopterinae), de diferentes tamanhos em um riacho da Floresta Atlântica, Paraná (Brasil). Acta Biológica Paranaense, 31: 137-150.

Vitule, J. R. S., M. R. Braga \& J. M. R. Aranha. 2008. Ontogenetic, spatial and temporal variations in the feeding ecology of Deuterodon langei Travassos, 1957 (Teleostei: Characidae) in a Neotropical stream from the Atlantic rainforest, southern Brazil. Neotropical Ichthyology, 6(2): 211-222.
Winemiller, K. O. 1989. Ontogenetic diet shifts and resource partitioning among piscivorous fishes in Venezuelan Llanos. Environmental Biology of Fishes, 26: 177-199.

Wooton, J. H. 1999. Ecology of teleost fish. The Netherlands, Kluwer Academic Publishers, 386p.

Accepted April 20, 2009

Published September 30, 2009 